\title{
Breeding and exploitation of prolific breeds in Czechoslovakia
}

\author{
V. JAKUBEC and J. KŘIŽEK \\ Research Institute of Animal Production, 10400 Praha, \\ 10-Uhřinèves, Czechoslovakia
}

\begin{abstract}
In the years 1971 - 1979 many experiments were conducted in order to elucidate problems of meat production increase in sheep. Ewes of native breeds (Mutton Merino $=\mathrm{M}$, Improved Wallachian $=\mathrm{I}$ ) were mated to rams of prolific breeds (Finnsheep $=\mathrm{F}$, Romanov $=\mathrm{R}$ ), producing $\mathrm{F} 1$ crossbred females. The crossbred ewes were mated to rams of a third mutton breed (Texel, Dorset Down, M) to produce meat lambs. In experiments from 1980 to 1987 on the basis of the $\mathrm{I}$ and the $\mathrm{R}$ and $\mathrm{F}$ crossbred combinations were produced to provide contemporary comparison of purebreds, F1, F2 and backcrosses, both to $\mathrm{I}$ and to $\mathrm{F}$ and R. The purebred and crossbred populations were analysed for the estimation of crossbreeding parameters necessary for the optimization of the formation of a synthetic dam breed. The reproduction characters which were analysed were fertility, prolificacy, mortality rate, litter size (born and weaned) and milk production. From the wool production characters the greasy wool production, clean wool production and mean fibre diameter were of interest. From the production characters the following were analysed: birth, weaning and slaughter weights, daily gain from birth to weaning or slaughter, carcass weight and other carcass value traits.
\end{abstract}

Index words: Finnsheep, Romanov, Improved Wallachian, Mutton Merino, Tsigaya, crossbreeding, reproduction, meat production, wool production, milk production, adaptability, fertility, prolificacy, synthetic

\section{Introduction and experimental}

In the years $1971-79$ extensive experiments were carried out to elucidate problems of meat production increase in sheep. Ewes of native breeds (Mutton Merino $=\mathrm{M}$, Improved Wallachian $=\mathrm{I}$, and Tsigaya $=\mathrm{Ts}$ ) were mated to rams of prolific breeds (Finnsheep $=\mathrm{F}$, Romanov $=\mathrm{R}$ ) producing $\mathrm{F}$ 1 crossbred females. The purebred and crossbred ewes were mated to rams of a mutton breed $($ Texel $=\mathrm{T}$, Dorset Down $=\mathrm{D}$, and $\mathrm{M})$. The experiments were carried out in localities where the native breeds are kept. M is kept in lowland regions and Ts and I in mountainous and submountainous regions. Crossbreeding experiments on the basis of domestic dam breeds were carried out to evaluate the adapability of F1 dams and crossbred slaughter lambs to the given en- 
vironment. The purebred prolific breeds were kept together with the individuals of $\mathrm{M}$. With the exception of milk production characters, heterosis effects are estimated for all characters in crossbreds on the basis of $\mathrm{M}$ and prolific breeds.

The contribution is a survey and summary of results published in various papers in which reproduction and production characters were analysed by the least squares method.

\section{Reproduction}

From reproduction characters, conception rate (CR) and litter size (LS) of 3-yr. old ewes are given in table 1. CR is expressed by the number of ewes lambed per 100 ewes mated. The LS is expressed as lambs born (dead and alive) per ewe lambing. The impact of sire breeds on the reproduction characters of all purebred and crossbred ewes was in all cases non-significant $(2,3,5)$. For this reason the effect of the sire breeds on reproduction characters was disregarded in the analysis. Sire-dam crossbred means, dam breed means across all sire breeds and dam breed means are presented horizontally; sire-dam crossbred means, sire breed means across all dam breeds and sire breed means are presented vertically.

Ts was the best in CR and the worst in LS of all dam breeds. $M$ was the worst in $\mathrm{CR}$ and I the best in LS. Ts crossbred with prolific breeds showed the significant highest CR. M were the worst. In LS were the individual dam breed means across all sire breeds virtually the same. In purebreeding, $\mathrm{R}$ is a better sire breed than $\mathrm{F}$ both in terms of CR and LS. The differences between the sire breeds in crossbreeding in CR and LS are negligible. Differences in terms of CR did not exist between crossbred, dam breed and sire breed ewes. The array of ewes of individual genotypes with respect to LS was:

Purebred dam breeds -1.32 ; purebred sire breeds -2.04 ; crossbreds -1.70 .

\section{Wool production}

Greasy (GWP) and clean (CWP) wool production of 2 year old ewes are analysed in table $2(1,4,6)$. In the mentioned papers further wool characters were analysed: wool

Table 1. Conception rate (1) and litter size (2) of 3 year old ewes.

\begin{tabular}{|c|c|c|c|c|c|c|c|c|c|}
\hline \multirow[b]{2}{*}{$\begin{array}{c}\mathrm{P}_{2} \\
\text { Dam Breed }\end{array}$} & & \multicolumn{2}{|c|}{ R } & \multicolumn{2}{|c|}{ F } & \multicolumn{2}{|c|}{$\begin{array}{c}\text { Dam breed } \\
\text { means across } \\
\text { all sire breeds }\end{array}$} & \multicolumn{2}{|c|}{$\begin{array}{c}\text { Dam breed } \\
\text { means } \\
\mathrm{P}_{2} \\
\end{array}$} \\
\hline & & $\mathrm{n}$ & $\begin{array}{c}\% \\
\text { No. } \\
\text { lambs }\end{array}$ & $\mathrm{n}$ & $\begin{array}{c}\% \\
\text { No. } \\
\text { lambs }\end{array}$ & $\mathrm{n}$ & $\begin{array}{c}\% \\
\text { No. } \\
\text { lambs }\end{array}$ & $\mathrm{n}$ & $\begin{array}{c}\% \\
\text { No. } \\
\text { lambs }\end{array}$ \\
\hline & 1 & 35 & 77.14 & 97 & 82.56 & 132 & 79.83 & 114 & 77.46 \\
\hline M & 2 & 57 & 1.74 & 109 & 1.62 & 166 & 1.68 & 93 & 1.36 \\
\hline & 1 & 82 & 85.53 & 156 & 86.45 & 238 & 85.99 & 1572 & 90.37 \\
\hline 1 & 2 & 59 & 1.68 & 120 & 1.71 & 179 & 1.70 & 1310 & 1.43 \\
\hline & 1 & 118 & 89.70 & 113 & 95.25 & 231 & 92.47 & 223 & 92.65 \\
\hline is & 2 & 80 & 1.67 & 86 & 1.76 & 166 & 1.72 & 65 & 1.16 \\
\hline $\begin{array}{l}\text { Sire breed } \\
\text { means across }\end{array}$ & 1 & 235 & 84.12 & 366 & 88.08 & 601 & 86.10 & 1909 & 86.83 \\
\hline $\begin{array}{l}\text { all maternal } \\
\text { breeds }\end{array}$ & 2 & 196 & 1.70 & 315 & 1.70 & 511 & 1.70 & 1469 & 1.32 \\
\hline $\begin{array}{l}\text { Sire } \\
\text { breed } \quad P_{1} \\
\text { means }\end{array}$ & $\begin{array}{l}1 \\
2\end{array}$ & $\begin{array}{r}94 \\
135\end{array}$ & $\begin{array}{r}93.46 \\
2.12\end{array}$ & $\begin{array}{l}42 \\
47\end{array}$ & $\begin{array}{r}78.57 \\
1.96\end{array}$ & $\begin{array}{l}136 \\
182\end{array}$ & $\begin{array}{r}86.01 \\
2.04\end{array}$ & & \\
\hline
\end{tabular}


yield, percentage of wool fibre, average fibre diameter and fibre diameter class. I had the highest GWP and CWP in purebreds and crossbreds of native breeds. It is a semi-fine wool breed like Ts, but is even better than $\mathrm{M}$ (fine-wool breed). In Czechoslovakia on the average, $M$ have a higher GWP than I. The higher GWP of I was due to the fact that the experiment on this breed was carried out in one of the best nucleus flocks in Czechoslovakia. For wool production characters in purebreeding $\mathrm{F}$ is better than $\mathrm{R}$. For wool production characters in crossbreds both sire breeds are virtually equal. For both characters was the following array of genotypes from the lowest to the highest values: purebred sire breeds, crossbreds and purebred dam breeds.

\section{Milk production}

For randomly chosen groups of 2 and 3 year old ewes of I, F, R and crossbreds F $\times$ I, milk yield (MY) was studied for 12 weeks after parturition (7). This period was divided into two six-week periods. The MY study was based on the use of the oxytocin method after Mc CANCE (9). The data were analysed by the least squares method. The effects of LS, lactation order and lamb sex were considered. In table 3 the genotypes are analysed according to the amount of milk, fat and protein in kgs.

More than $60 \%$ of the milk is produced during the first period. Within 12 weeks of lactation the highest MY had I and the lowest $R$. In the same period the rank of genotypes

Table 2. Greasy (1) and clean (2) wool production.

\begin{tabular}{|c|c|c|c|c|c|c|c|c|c|}
\hline \multirow[b]{2}{*}{$\frac{\mathrm{P}_{2}}{\text { Dam Breed }}$} & & \multicolumn{2}{|c|}{$\mathbf{R}$} & \multicolumn{2}{|c|}{$\mathrm{F}$} & \multicolumn{2}{|c|}{$\begin{array}{c}\text { Dam breed } \\
\text { means across } \\
\text { all sire breeds }\end{array}$} & \multicolumn{2}{|c|}{$\begin{array}{c}\text { Dam breed } \\
\text { means } \\
\mathrm{P}_{2}\end{array}$} \\
\hline & & $\mathbf{n}$ & $\mathrm{kg}$ & $\mathrm{n}$ & $\mathrm{kg}$ & $\mathbf{n}$ & $\mathrm{kg}$ & $\mathrm{n}$ & $\mathrm{kg}$ \\
\hline M & $\begin{array}{l}1 \\
2\end{array}$ & 17 & $\begin{array}{l}2.92 \\
1.75\end{array}$ & 55 & $\begin{array}{l}2.85 \\
1.70\end{array}$ & 72 & $\begin{array}{l}2.89 \\
1.73\end{array}$ & 62 & $\begin{array}{l}3.82 \\
2.03\end{array}$ \\
\hline I & $\begin{array}{l}1 \\
2\end{array}$ & 18 & $\begin{array}{l}3.30 \\
2.37\end{array}$ & 57 & $\begin{array}{l}3.58 \\
2.68\end{array}$ & 75 & $\begin{array}{l}3.44 \\
2.53\end{array}$ & 81 & $\begin{array}{l}3.93 \\
2.91\end{array}$ \\
\hline Ts & $\begin{array}{l}1 \\
2 \\
\end{array}$ & 69 & $\begin{array}{l}2.76 \\
1.73 \\
\end{array}$ & 63 & $\begin{array}{l}2.72 \\
1.66 \\
\end{array}$ & 132 & $\begin{array}{l}2.74 \\
1.70\end{array}$ & 137 & $\begin{array}{l}2.97 \\
1.93 \\
\end{array}$ \\
\hline $\begin{array}{l}\text { Sire breed } \\
\text { means across } \\
\text { all maternal } \\
\text { breeds }\end{array}$ & $\begin{array}{l}1 \\
2\end{array}$ & 104 & $\begin{array}{l}2.99 \\
1.95\end{array}$ & 177 & $\begin{array}{l}3.05 \\
2.01\end{array}$ & 281 & $\begin{array}{l}3.02 \\
1.98\end{array}$ & 280 & $\begin{array}{l}3.57 \\
2.29\end{array}$ \\
\hline $\begin{array}{l}\text { Sire } \\
\text { breed } \quad P_{1} \\
\text { means }\end{array}$ & $\begin{array}{l}1 \\
2\end{array}$ & 17 & $\begin{array}{l}0.74 \\
0.52\end{array}$ & 10 & $\begin{array}{l}1.82 \\
1.18\end{array}$ & 27 & $\begin{array}{l}1.28 \\
0.85\end{array}$ & & \\
\hline
\end{tabular}

Table 3. Yields of milk, fat and protein in the first 12 weeks of lactation.

\begin{tabular}{lcccccc}
\hline Breed & \multicolumn{4}{c}{ Milk yield (MY) } \\
\cline { 2 - 7 } & $\mathrm{n}$ & $\begin{array}{c}1 \text { st-6th } \\
\text { week } \\
\mathrm{kg}\end{array}$ & $\begin{array}{c}7 \text { th-12th } \\
\text { week } \\
\mathrm{kg}\end{array}$ & $\begin{array}{c}1 \mathrm{st}-12 \text { th } \\
\text { week } \\
\mathrm{kg}\end{array}$ & $\begin{array}{c}\text { Milk } \\
\text { fat } \\
\mathrm{kg}\end{array}$ & $\begin{array}{c}\text { Milk } \\
\text { protein } \\
\mathrm{kg}\end{array}$ \\
\hline $\mathrm{I}$ & 24 & 75.5 & 49.2 & 124.7 & 8.89 & 5.16 \\
$\mathrm{~F}$ & 9 & 64.5 & 41.9 & 106.4 & 7.87 & 5.50 \\
$\mathrm{R}$ & 21 & 58.0 & 38.5 & 96.5 & 7.27 & 4.86 \\
$\mathrm{~F} \times 1$ & 8 & 67.2 & 33.3 & 100.6 & 6.51 & 4.37 \\
\hline
\end{tabular}


for milk fat production corresponds with the rank of genotypes for MY with the exception of $\mathrm{R}$. The highest protein production was shown by $\mathrm{F}$ and the lowest by the crossbred $\mathrm{F} \times \mathrm{I}$.

\section{Meat production}

Table 4 contains the results of the meat production analysis $(10,11)$. Body weight (BW) at 60 days, average daily gain (ADG) from 20 to $40 \mathrm{~kg}$, starch unit intake per $1 \mathrm{~kg}$ gain, eye muscle area and leg proportions are shown for lambs of pure breeds, single crosses and three-way crosses. The highest BW at 60 days was that of lambs whose dams were $\mathrm{M}$ or crossbreds descending from $\mathbf{M}$. The highest ADG and the lowest values of starch unit intake per $\mathrm{kg}$ gain were shown by $\mathrm{T} \times$ $\mathrm{M}$ and $\mathrm{T} \times(\mathrm{R} \times \mathrm{M})$ genotypes. The $\mathrm{R} \times$ I crossbreds and I had the lowest ADG. R lambs had the highest starch unit intake per $\mathrm{kg}$ gain. All single and three-way crosses with a share of $\mathrm{T}$ genes had the largest eye muscle area. $\mathbf{M}$ had the best leg proportions, crossbreds $\mathrm{F} \times \mathrm{Ts}$ had the worst.

\section{Heterosis}

In table 5 estimates of heterosis effects for reproduction and production characters are shown in absolute and relative values. The data facilitated the estimation of individual heterosis effects $\left(h_{1}\right)$ for wool production characters and maternal heterosis effects for reproductive characters.

The following models were used:

Reproduction and wool production characters

$\mathrm{h}_{\mathrm{l}_{(\mathrm{m})}}=\frac{\mathrm{RM}+\mathrm{FM}}{2}-\frac{2 \mathrm{M}+\mathrm{R}+\mathrm{F}}{4}$

Milk production characters

$\mathrm{h}_{\mathrm{I}}=\mathrm{FI}-\frac{\mathrm{F}+\mathrm{I}}{2}$

Fattening and carcass quality characters

$\mathrm{h}_{\mathrm{l}}=\mathrm{RM}-\frac{\mathrm{R}+\mathrm{M}}{2}$

From experiments resulted that positive values of heterosis effects showed only the GFW, CWP, BW at 60 days and ADG. The

Table 4. Fattening and carcass quality characters.

\begin{tabular}{|c|c|c|c|c|c|c|}
\hline Genotype & $\mathrm{n}$ & $\begin{array}{c}\text { BW } \\
\text { at } 60 \mathrm{~d} . \\
\mathrm{kg}\end{array}$ & $\begin{array}{c}\text { ADG } \\
\text { from } 20 \text { to } \\
40 \mathrm{~kg} \\
\mathrm{~g}\end{array}$ & $\begin{array}{c}\text { Starch } \\
\text { unit intake } \\
\text { per } 1 \mathrm{~kg} \text { gain }\end{array}$ & $\begin{array}{c}\text { Eye } \\
\text { muscle } \\
\text { area } \\
\mathrm{cm}^{2}\end{array}$ & $\begin{array}{c}\text { Propor- } \\
\text { tion of } \\
\text { leg } \\
\%\end{array}$ \\
\hline $\mathbf{R}$ & 19 & 16.39 & 199 & 5.53 & 12.46 & 32.49 \\
\hline M & 82 & 17.25 & 222 & 3.70 & 12.22 & 34.26 \\
\hline I & 73 & 16.43 & 168 & 4.57 & 10.90 & 32.00 \\
\hline Ts & 46 & 15.43 & 177 & 4.35 & 11.51 & 32.38 \\
\hline $\mathrm{R} \times \mathrm{M}$ & 41 & 18.16 & 212 & 4.21 & 12.17 & 33.13 \\
\hline$R \times I$ & 33 & 16.70 & 166 & 4.50 & 11.18 & 31.94 \\
\hline $\mathrm{R} \times \mathrm{Ts}$ & 46 & 14.44 & 191 & 4.50 & 11.49 & 31.35 \\
\hline $\mathrm{F} \times \mathrm{M}$ & 29 & 18.86 & 212 & 3.97 & 12.01 & 32.98 \\
\hline $\mathrm{F} \times \mathrm{I}$ & 20 & 16.53 & 175 & 4.44 & 11.18 & 31.13 \\
\hline $\mathrm{F} \times \mathrm{Ts}$ & 39 & 14.56 & 204 & 4.25 & 11.29 & 30.52 \\
\hline $\mathrm{T} \times \mathrm{M}$ & 38 & 17.18 & 284 & 2.69 & 13.64 & 32.47 \\
\hline$T \times I$ & 42 & 15.92 & 203 & 3.90 & 13.09 & 32.36 \\
\hline $\mathrm{T} \times \mathrm{Ts}$ & 19 & 14.38 & 219 & 3.90 & 13.22 & 32.55 \\
\hline $\mathrm{T} \times(\mathrm{R} \times \mathrm{M})$ & 25 & 19.60 & 256 & 2.85 & 13.76 & 32.47 \\
\hline $\mathrm{T} \times(\mathrm{R} \times \mathrm{I})$ & 22 & 16.22 & 223 & 3.06 & 13.08 & 32.42 \\
\hline $\mathrm{T} \times(\mathrm{R} \times \mathrm{Ts})$ & 20 & 14.34 & 198 & 4.47 & 11.76 & 32.60 \\
\hline $\mathrm{T} \times(\mathrm{F} \times \mathrm{M})$ & 15 & 19.65 & 205 & 3.69 & 13.06 & 32.38 \\
\hline $\mathrm{T} \times(\mathrm{F} \times \mathrm{I})$ & 20 & 15.96 & 209 & 3.82 & 13.34 & 31.90 \\
\hline $\mathrm{T} \times(\mathrm{F} \times \mathrm{Ts})$ & 18 & 14.62 & 213 & 3.90 & 12.79 & 31.68 \\
\hline
\end{tabular}


heterosis for the ADG was very slow. If we assume that heterosis is expressed only by means of positive parameters, then the other characters did not show heterosis.

\section{Formation of a synthetic breed}

The experiments in the seventies had shown that a two-way crossbreeding system would be more effective than a three-way one, if a prolific and well adapted synthetic dam population would replace the $F_{1}$ prolific dams. In the eighties a maternal synthetic population is being formed under farm-scale conditions in submountaineous regions on the basis of $\mathrm{I}$. The ewes were mated by $\mathrm{R}$ rams and gradually crossbred generations $\mathrm{F}_{1}, \mathrm{~F}_{2}, \mathrm{~B}_{1}$ and $\mathrm{B}_{\text {Irec. }}$. were produced. Besides these generations also both parental populations are analysed. Preliminary results including estimated individual and maternal heterosis effects were published by K ŘiŽEK and JAKUBEC (8).

In table 6 the main performance data of the experiment are shown. The experiment will be concluded in 1988, the data analysed, the genetic parameters estimated and a new synthetic population with the optimal gene proportion of both parental populations proposed. The most important character is the LS and therefore only the LS results will be discussed. The difference between both parental populations was 1.11 lambs. It is obvious that only in the $\mathrm{B}_{1}$ is heterosis realized. This can be influenced by the maternal heterosis and the maternal effect of $\mathrm{R}$. This can be also the reason for the higher LS of $F_{2}$ than $F_{1}$.

Table 5. Maternal heterosis for reproduction characters and individual heterosis for production characters.

\begin{tabular}{lcr}
\hline Character & \multicolumn{2}{c}{$\mathrm{h}_{\mathrm{l}}$} \\
\cline { 2 - 3 } & abs. & rel. $\%$ \\
\hline Conception rate \% & -1.91 & -2.33 \\
Litter size, no. of lambs & -0.02 & -1.17 \\
Greasy wool prod., kg & +0.34 & +13.33 \\
Clean wool prod., kg & +0.29 & +20.14 \\
Milk production kg & -14.95 & -12.90 \\
Milk Fat prod., kg & -1.87 & -22.30 \\
Milk Protein prod., kg & -0.96 & -18.00 \\
Body weight at $60 \mathrm{days}, \mathrm{kg}$ & +1.34 & +8.00 \\
Aver.daily gain from 20 to & & +0.70 \\
40 kg, g & +1.50 & -8.90 \\
Starch unit intake per & & -1.40 \\
1 kg gain & -0.41 & -0.70 \\
Eye muscle area, cm ${ }^{2}$ & -0.17 & \\
Proportion of leg, \% & -0.25 & \\
\hline
\end{tabular}

Table 6. Generation means for reproduction and wool production characters.

\begin{tabular}{lcccc}
\hline Breed & $\mathrm{n}$ & $\begin{array}{c}\text { Number } \\
\text { of lambs } \\
\text { per ewe }\end{array}$ & $\begin{array}{c}\text { Live weight } \\
\text { at } 60 \mathrm{~d} . \\
\mathrm{kg}\end{array}$ & $\begin{array}{c}\text { Greasy wool } \\
\text { production } \\
\mathrm{kg}\end{array}$ \\
\hline $\mathrm{P}_{1}-\mathrm{I}$ & 267 & 1.36 & 14.25 & 3.83 \\
$\mathrm{P}_{2}-\mathrm{R}$ & 26 & 2.47 & 15.35 & 2.18 \\
$\mathrm{~F}_{1}-\mathrm{R} \times \mathrm{I}$ & 261 & 1.68 & 13.80 & 3.43 \\
$\mathrm{~F}_{2}-\mathrm{RI} \times \mathrm{RI}$ & 15 & 1.80 & 14.39 & 3.30 \\
$\mathrm{~B}_{1}-\mathrm{I} \times \mathrm{RI}$ & 47 & 1.87 & 16.25 & 3.73 \\
$\mathrm{~B}_{1 \text { ree }}-\mathrm{RI} \times \mathrm{I}$ & 155 & 1.47 & 15.38 & 3.91 \\
\hline
\end{tabular}

\section{References}

1. JAKUBEC, V. \& LindovskÝ, R. 1976. Quantitative and qualitative production of wool of Mutton Merino breed, prolific breeds and their crossbreds $F_{1}$. Scient. Agric. Bohemosl. 8, 4: 271-278.
2. Jakubec, V., KŘižé, J. \& Sl.aná, O. 1977. Reproduction of Mutton Merino sheep and their hybrids with prolific breeds. Scient. Agric. Bohemosl., 9, 1: 39-46. 
3. Jakubec, V., KŘižek, J. \& Slaná, O. 1978a. Reprodukce křiženek mezi domácími plemeny (žirné merino, cigája) a plodnými plemeny [Reproduction of crossbreds between native breeds (Mutton Merino, Tsigai) and prolific breeds]. Živočišná výroba, 23, 3: 191-198.

4. JaKuBeC, V., KŘiŽEK, J., LindovskÝ, R. \& PINĎÁK, A 1978b. Kvantitativní a kvalitativni produkce vlny plemene cigája a jeho křiženců s plodnými plemeny (Quantitative and qualitative production of wool of Tsigai sheep and their crosses with prolific breeds). Živočišná výroba, 23, 6: 405-414.

5. JAKuBEC, V., KŘiŽeK, J. \& LOUdA, F. 1979. Reproduction of Improved Wallachian sheep and their crossbreds with prolific breeds. Scient. Agric. Bohemosl. 11, 1: 33-37.

6. JaKuBEc, V., KŘižEK, J., LindovsKÝ, R. \& PinĎÁK, A. 1980. Kvantitativní a kvalitativní produkce vlny zušlechtěných valašek a jejich křiženců s plodnými plemeny (Quantitative and qualitative wool production of Improved Wallachian sheep and their crosses with prolific breeds). Živočišná výroba, 25, 5: $321-327$.

7. KŘižeK, J., LoudA, F., JaKubec, V. \& DOney, J.M.
1978. Analýza mléčné produkce ovcí plemene zušlechtěná valaška, plodných plemen a jejich křiženek (Analysis of milk production in the Improved Wallachian breed, prolific breeds and their crossbreds). Živočišná výroba, 23, 6: 461-470.

8. KŘižeK, J., JAKuBEC, V. \& ŘHÁČeK, E. 1986. Estimates of crossbred parameters and their exploitation in forming of a synthetic line of sheep. 37th Ann. Meet. E.A.A.P., Budapest, (Comm. Anim. Genet. and Sheep \& Goat Prod.), Vol. 1: 86-87.

9. Mc CANCE, I. 1959. The determination of milk yield in the Merino sheep. Aust. J. Agric. Res., 10: $839-853$.

10. Slaná, O. \& JaKubec, V. 1976. Výkrmnost a jatečná hodnota jehňat při trojplemennén užitkovém křižení ovcí. (Fattening capacity and carcass value of lambs in three-breed commercial crossing). Živočišná výroba, 21, 8: 587-598.

11. Slana, O., Jakubec, V., KŘižze, J. \& Poděbradský, Z. 1983. Hodnoceni masné užitkovosti jehňat při hybridizaci ve staničních podmínkách. (Evaluation of meat production of lambs under station conditions). Mezinárodni sympozium o produkci a kvalitě masa, Nitra: $423-429$. 